\title{
АНТИГИПОКСИЧЕСКАЯ АКТИВНОСТЬ \\ 6-АРИЛ-4-ГИДРОКСИ-5,6-ДИГИДРО-4Н-1,3-ОКСАЗИНОВ
}

\author{
СВЕТЛАНА СЕРГЕЕВНА ЗЫКОВА, канд. фарм. наук, доцент кафедры зоотехнии ФКОУ ВПО «ПермСКий институт \\ ФСИН России», Пермь, Россия, тел. 8-909-731-09-74, e-mail: zykova.sv@rambler.ru
}

\begin{abstract}
Реферат. Цель исследования - поиск соединений среди 6-арилзамещенных-4-бензоилацетил-4-гидрокси-5,6дигидро-4Н-1,3-оксазинов с антигипоксической активностью. Материал и методы. Исследована антигипоксическая активность семи 6-арилзамещенных-4-бензоилацетил-4-гидрокси-5,6-дигидро-4Н -1,3-оксазинов, полученных реакцией 1,6-диарил-3,4-дигидрокси-2,4-гексадиен-1,6-диона с разнообразными основаниями Шиффра. На двух моделях гипоксии - нормобарической с гиперкапнией и гемической - изучена противогипоксическая активность синтезированных соединений. В качестве препарата сравнения использовался современный антиоксидант и антигипоксант «Мексидол». Результаты и их обсуждение. Оценку противогипоксического действия проводили по времени увеличения продолжительности жизни мышей в условиях острой гипоксии. Синтезированные соединения показали умеренную и высокую антигипоксантную активность.

Ключевые слова: оксазины, антигипоксическая активность, нормобарическая гипоксия, гемическая гипоксия, мексидол.
\end{abstract}

\section{ANTIHYPOXIC ACTIVITY OF 6-ARYL-4-HYDROXY-5,6-DIHYDRO-4H-1,3-OXAZINES}

SVETLANA S. ZYKOVA, PhD (Pharm), associate professor of chair zootechnology of the FSEl HPE «Federal Penitentiary Service Institute of Russia", Perm, Russia, tel. 8-909-731-09-74,

e-mail: zykova.sv@rambler.ru

Abstract. The purpose of research - find connections among 6-arylsubstituted-benzoilatsetil-4-hydroxy-5,6-dihydro$4 \mathrm{H}-1,3-0 x a z i n e s$ with antihypoxic activity. Materials and Methods.Antihypoxic activity studied seven 6-aryl-substituted4-benzoilatsetil-4-hydroxy-5,6-dihydro-4H-1,3-oxazine, obtained by reacting 1,6-diaryl-3,4-dihydroxy-2,4-hexadiene1,6-dione with multiple Schiff bases. On two models of hypoxia - hypercapnia with normobaric and hemic - studied antihypoxic synthesized compounds. As a comparison drug used modern antioxidant and antihypoxant «Meksidol». Results and discussion. Assessment antihypoxic actions performed over time to increase life expectancy of mice under conditions of acute hypoxia. The synthesized compounds showed moderate and high antihypoxic activity.

Key words: oxazines, antihypoxic activity, normobaric hypoxia, hemic hypoxia, mexidol.

B ведение. Известно, что гетероциклические соединения обладают противомикробной, противовоспалительной, противосудорожной и другими видами биологической активности [1]. Синтез новых гетероциклических систем является одной из актуальных прикладных задач органической химии.

Источником для большого числа биологически активных гетероциклов являются реакции 1,3,4,6тетракарбонильных систем с различными нуклеофильными агентами [2]. Среди тетракарбонилов особый интерес представляет 1,6-диарил-3,4-дигидрокси2,4-гексадиен-1,6-дион, в растворе имеющий смесь таутомерных форм (Ix, ly, Iz) (рuc. 1)

Структура его имеет сходство с природным поликарбонилом - халконом, обладающим широкой биологической активностью [3].

Реакция 1,6-диарил-3,4-дигидрокси-2,4-гексадиен1,6-диона с арилиденариламинами (основаниями Шиффа) в среде протофильных растворителей приводит к 6-арилзамещенным-4-бензоилацетил-4-гидрокси5,6-дигидро-4Н-1,3-оксазинам (рис. 2), которые представляют собой кристаллические вещества, нерас- творимые в воде, растворимые в бензоле, толуоле, диметилсульфоксиде [4].

Спектральные данные полностью доказали структуру и наличие таутомерных форм 6-арилзамещенных4-бензоилацетил-4-гидрокси-5,6-дигидро-4Н-1,3-оксазинов.

Целью настоящих исследований явился поиск среди полученных 6-арилзамещенных-1,3-оксазинов соединений с антигипоксической активностью.

Материал и методы. Объектами изучения биологической активности стали семь соединений. В табл. 1 приведены структурные формулы радикалов в составе 6-арилзамещенных 1,3-оксазинов.

Современные исследования доказали, что особая роль в развитии патологических процессов различного генеза принадлежит свободным радикалам (СР) и свободно-радикальному окислению (CPO) [5].

Исследования свободно-радикального окисления доказали, что пул свободных радикалов возникает в состоянии гипоксии и последующей реперфузии, что приводит к дефициту антиоксидантной системы. 


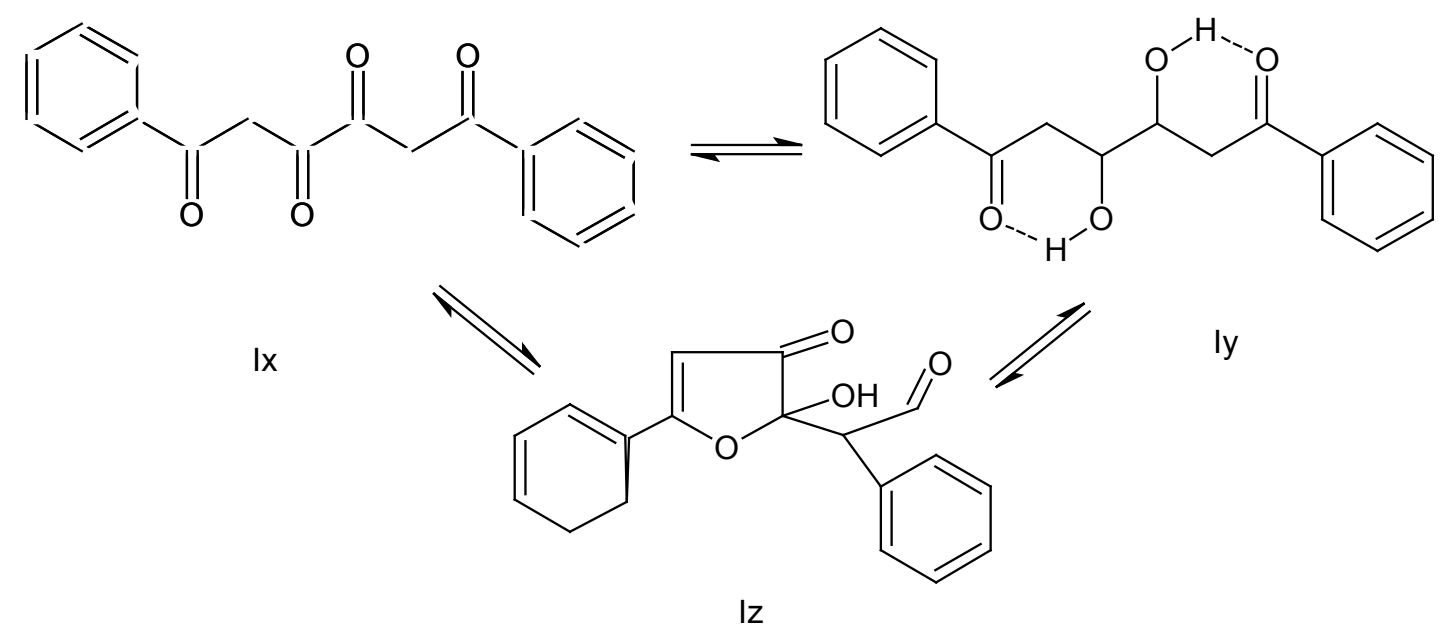

Рис. 1. Схема образования таутомерных форм 1,6-диарил-3,4-дигидрокси-2,4-гексадиен-1,6-диона (Ix, ly, Iz)<smiles>[R2]N1C([R])([2H])OC(c2ccccc2)=CC1([R])C(=O)CC(=O)C1C=CC=CC1</smiles>

IIx<smiles>[R]N1C([R])([2H])OC(c2ccccc2)=CC1(O)/C(O)=C/C(=O)C1C=CC=CC1</smiles>

IIy

Рис. 2. Общие формулы кетонной (IIx) и енольной (Ily) таутомерных форм 6-арилзамещенных-4-бензоилацетил-4-гидрокси-5,6-дигидро-4Н-1,3-оксазинов

Т а блиц а 1

Структурные формулы радикалов в составе 6-арилзамещенных-4-бензоилацетил-4-гидрокси-5,6дигидро-4Н-1,3-оксазинов

\begin{tabular}{|c|c|c|}
\hline \multirow{2}{*}{ Соединения } & \multicolumn{2}{|c|}{ Радикалы } \\
\cline { 2 - 3 } & $\mathrm{R}^{1}$ & \multicolumn{1}{c|}{$\mathrm{R}^{2}$} \\
\hline Ilа & $\mathrm{C}_{6} \mathrm{H}_{5}$ & $\mathrm{C}_{6} \mathrm{H}_{5}$ \\
\hline IIб & $\mathrm{p}-\mathrm{CH}_{3} \mathrm{C}_{6} \mathrm{H}_{4}$ & $\mathrm{C}_{6} \mathrm{H}_{5}$ \\
\hline IIв & $\mathrm{p}-\mathrm{CH}_{3} \mathrm{C}_{6} \mathrm{H}_{4}$ & $\mathrm{p}-\mathrm{CH}_{3} \mathrm{C}_{6} \mathrm{H}_{4}$ \\
\hline IIг & $\mathrm{p}-\mathrm{NO}_{2} \mathrm{C}_{6} \mathrm{H}_{4}$ & $\mathrm{C}_{6} \mathrm{H}_{5}$ \\
\hline IIд & $\mathrm{p}-\mathrm{CH}_{3} \mathrm{OC}_{6} \mathrm{H}_{4}$ & $\mathrm{p}-\mathrm{NO}_{2} \mathrm{C}_{6} \mathrm{H}_{4}$ \\
\hline Ile & $\mathrm{p}-\mathrm{NO}_{2} \mathrm{C}_{6} \mathrm{H}_{4}$ & $\mathrm{p}-\mathrm{BrC}_{6} \mathrm{H}_{4}$ \\
\hline IІж & $\mathrm{p}-\mathrm{NO}_{2} \mathrm{C}_{6} \mathrm{H}_{4}$ & $\mathrm{p}-\mathrm{CH}_{3} \mathrm{C}_{6} \mathrm{H}_{4}$ \\
\hline
\end{tabular}

Одним из значимых механизмов антиоксидантов является их антигипоксическая активность. Значительная часть антиоксидантов повышает устойчивость клеток и тканей к гипоксии, что делает поиск антиоксидантов и антигипоксантов актуальным.

Известным препаратом - антиоксидантом с антигипоксическими активностью является мексидол [6].

Действующим веществом в препарате «Мексидол» (производство «Фармасофт») выступает этилметилгидроксипиридинасукцинат. Мексидол является со- временным высокоэффективным антиоксидантом и антигипоксантом прямого действия. Он ингибирует свободно-радикальные процессы и перекисное окисление липидов, мембраностабилизирующее действие, повышает содержание полярных фракций липидов, оказывает гиполипидемическое действие, уменьшая уровень общего холестерина, липопротеидов низкой плотности, снижает соотношение холестерин/фросфолипиды.

Мексидол улучшает энергосинтезирующую функцию митохондрий, тем самым стабилизируя энергообмен клетки и стимулируя прямое окисление глюкозы по пентозофоссратному шунту, повышая уровень восстановленных нуклеотидов (НАДФН) и тем самым усиливает антиоксидантную защиту клетки, стабилизируя уровень эндогенных антиоксидантов.

Мексидол ингибирует синтез тромбоксанов, лейкотриенов и улучшает реологические свойства крови. Являясь «ловушкой» для свободных радикалов, мексидол способствует повышению активности антиоксидантных ферментов, в частности супероксиддисмутазы [6].

Мексидол оказывает выраженное антигипоксическое и противоишемическое действие. Активация сукцинатоксигеназного пути окисления при гипоксии 
способствует повышению резистентности клеток к дефициту кислорода и определяет механизм его антигипоксического действия.

Таким образом, механизм действия мексидола определяют, прежде всего, его антиоксидантные и антигипоксантные свойства.

Терапевтические эффректы мексидола составляют при применении от 10 до 300 мг/кг. Время достижения максимальной концентрации в плазме крови приблизительно составляет 30 мин.

В настоящее время мексидол широко используют при острых нарушениях мозгового кровообращения, черепно-мозговых травмах, эпилепсии, алкогольном абстинентном синдромом, острых интоксикациях нейролептиками и др.

Антигипоксическая активность изучалась на модели гемической, а также на модели нормобарической гипоксии с гиперкапнией [7].

Исследование антигипоксической активности проводили на белых мышах - самцах массой 18-20 г, содержащихся в стандартных условиях вивария.

Острую гемическую гипоксию вызывали внутрибрюшинным введением метгемоглобинообразователя нитрита натрия в дозе 100 мг/кг. Исследуемые соединения и эталон сравнения в дозе 100 мг/кг вводили внутрибрюшинно в виде суспензии с изотоническим раствором хлорида натрия за 30 мин до начала эксперимента. В качестве эталона сравнения использовали лекарственный препарат мексидол в дозе 100 мг/кг. Считали время жизни мышей (в минутах). Результаты исследований приведены в табл. 2.

Та блица 2

Антигипоксическая активность 6-арилзамещенных-

4-бензоилацетил-4-гидрокси-5,6-дигидро-4Н-1,3оксазинов на модели гемической гипоксии (ІІа-ж)

\begin{tabular}{|l|c|c|}
\hline \multicolumn{1}{|c|}{$\begin{array}{c}\text { Исследуемые } \\
\text { объекты }\end{array}$} & $\begin{array}{c}\text { Время жизни, } \\
\mathrm{t}, \text { мин }\end{array}$ & $\begin{array}{c}\text { Прирост времени } \\
\text { жизни, \% }\end{array}$ \\
\hline Ila & $19,0 \pm 0,74^{*}$ & 61,0 \\
\hline IIб & $18,3 \pm 0,91$ & 55,2 \\
\hline IIв & $25,7 \pm 1,22^{*}$ & 117,8 \\
\hline IIг & $18,7 \pm 1,36$ & 58,4 \\
\hline IIд & $19,5 \pm 1,14^{*}$ & 65,2 \\
\hline Ile & $17,3 \pm 0,98$ & 46,6 \\
\hline IIж & $16,8 \pm 0,94$ & 42,3 \\
\hline Мексидол 100 мг/кг & $12,7 \pm 0,34^{*}$ & 7,6 \\
\hline $\begin{array}{l}\text { Контроль (0,9\% } \\
\text { хлорид натрия) }\end{array}$ & $11,8 \pm 0,55$ & - \\
\hline
\end{tabular}

*Изменения показателей статистически значимы $(p \leq 0,05)$ относительно контрольной группы.

Исследование антигипоксической активности проводили на модели экзогенной нормобарической гипоксии с последующей гиперкапнией.

Острую экзогенную нормобарическую гипоксию вызывали методом размещения лабораторных животных в банки равного объема и формы с герметично закрывающимися крышками и объемом 200 мл. Отсчет времени проводили с момента герметизации банок.

Результаты и их обсуждение. Механизмы развития гемической и нормобарической гипоксии разные, при этом гипоксические воздействия различного генеза приводят к активации механизмов «глубокого резерва», которые связаны с пулом стволовых клеток [8]. Не менее важным фактором, влияющим на устойчивость клеток к гипоксии, является активация сукцинатде- гидрогеназного окислительного пути и восстановление активности цитохромоксидазы [9]. Данный механизм характерен для янтарной кислоты и ее солей - сукцинатов. Возможным механизмом, проявляющимся у антигипоксантов, является мембраностабилизирующее действие, которое связно с антиоксидантным действием синтезированных соединений.

Антигипоксический эффект определялся по продолжительности жизни мышей в эксперименте по сравнению с контролем (табл. 3) [7].

Таблица 3

Результаты исследований 6-арилзамещенных-4бензоилацетил-4-гидрокси-5,6-дигидро-4Н-1,3-оксазинов при нормобарической гипоксии (IIa-ж)

\begin{tabular}{|l|c|c|}
\hline Исследуемые объекты & $\begin{array}{c}\text { Время жизни, } \\
\text { t, мин }\end{array}$ & $\begin{array}{c}\text { Прирост времени } \\
\text { жизни, \% }\end{array}$ \\
\hline Контроль $(0,9 \% \mathrm{NaCl})$ & $20,3 \pm 0,92$ & - \\
\hline Ila & $20,7 \pm 1,10^{*}$ & 1,97 \\
\hline IIб & $22,3 \pm 0,60$ & 9,85 \\
\hline Ilв & $20,8 \pm 1,41$ & 2,46 \\
\hline IIг & $30,6 \pm 4,64^{*}$ & 50,73 \\
\hline IIд & $25,7 \pm 1,98^{*}$ & 16,76 \\
\hline Ile & $23,5 \pm 0,75$ & 15,70 \\
\hline ІІж & $22,7 \pm 1,14^{*}$ & 11,82 \\
\hline Мексидол 100 мг/кг & $21,5 \pm 0,49$ & 5,93 \\
\hline
\end{tabular}

*Показатели статистически значимы $(p \leq 0,05)$ относительно контроля.

В результате исследований на моделях гемической и нормобарической гипоксии было отмечено значительное увеличение времени жизни. На модели гемической гипоксии наиболее активным является соединение ІІв. Увеличение продолжительности жизни мышей в условиях гемической гипоксии составило 117,8\% по отношению к контролю. Наиболее активным на модели нормобарической гипоксии явилось соединение IIr. Увеличение времени жизни составило 50,73\%.

Заключение. В присутствии синтезированных 6-арилзамещенных-1,3-оксазинов значительно увеличивается время жизни мышей на моделях гемической и нормобарической гипоксии и превышает данный показатель у препарата сравнения.

В модели гемической гипоксии соединение ІІв увеличивало время жизни мышей на $117,8 \%$. Исследования антигипоксической активности на модели нормобарической гипоксии показали, что наиболее эффективным было соединение ІІг, которое увеличивало продолжительность жизни мышей на $50,73 \%$.

Исследования показали, что среди 6-арилзамещенных-4-бензоилацетил-4-гидрокси-5,6-дигидро-

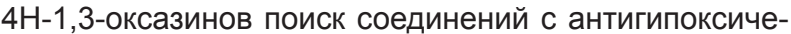
ской активностью является актуальным и перспективным.

\section{ЛИТЕРАТУРА}

1. Пидэмский, Е.Л. Скрининг и изучение механизма действия флоголитиков, нейротропных и противомикробных средств / Е.Л. Пидэмский, Р.P. Махмудов. - Пермь: Перм. ун-т, 2008. - $116 \mathrm{c}$.

2. Ширинкина, С.С. Взаимодействие 1,3,4,6-тетракарбонильных соединений с арилиденариламинами / С.С. Ширинкина, Н.М. Игидов, В.О. Козьминых / Материалы Юбилейной межвуз. науч.-практ. конф. проф.-преп. состава, посвящ. 275-летию города Перми и 80-летию фарм. образования на Урале. - Пермь, 1998. - С.62-63. 
3. Кулинский, В.И. Активные фрормы кислорода и оксидативная модификация макромолекул: польза, вред и защита / В.И. Кулинский // Соросовский образовательный журнал. - 1999. - № 1. - С.2-7.

4. Miranda, C.L. Cytotoxic and antiproliferative effects of prenylatetchalcones in human cancer cell lines and in cultured ret hepatocytes / C.L. Miranda, J.F. Stevens, A. Helmrich // Food Chem. Toxicol. — 1999. — № 37 (9). — P.271-285

5. Мексидол: рекомендации по применению. - М., 2005. $20 \mathrm{c}$.

6. Чеснокова, Н.П. Общая характеристика источников образования свободных радикалов и антиоксидантных систем / Н.П. Чеснокова, Е.В. Понукалин, М.Н. Бизенкова // Успехи современного естествознания (мед. науки). — 2006. № 7. - C.37-41.

7. Хабриев, Р.У. Руководство по экспериментальному (доклиническому) изучению новых фармакологических веществ / Р.У. Хабриев. - М., 2000. - 155 с.

8. Зюзьков, Г.Н. Роль стволовых клеток в адаптации к гипоксии и механизмы нейропротективного действия гранулоцитарного колониестимулирующего фактора / Г.Н. Зюзьков, Н.И. Суслов, А.М. Дыгай [и др.] // Клеточные технологии в биологии и медицине. - 2005. - № 4. - С.202-208.

9. Маевский, Е.И. Коррекция метаболического ацидоза путем поддержания функций митохондрий / Е.И. Маевский. Пущино: ИТЭБФ РАН, 2001. - 155 с.

\section{REFERENCES}

1. Pidemskii, E.L. Skrining i izuchenie mehanizma deistviya flogolitikov, neirotropnyh i protivomikrobnyh sredstv / E.L. Pidemskii, R.R. Mahmudov. - Perm': Perm. un-t, 2008. $-116 \mathrm{~s}$
2. Shirinkina, S.S. Vzaimodeistvie 1,3,4,6-tetrakarbonil'nyh soedinenii s arilidenarilaminami / S.S. Shirinkina, N.M. Igidov, V.O. Koz'minyh / Materialy YUbileinoi mezhvuz. nauch.-prakt. konf. prof.-prep. sostava, posvyasch. 275-letiyu goroda Permi i 80-letiyu farm. obrazovaniya na Urale. - Perm', 1998. S.62-63.

3. Kulinskii, V.I. Aktivnye formy kisloroda i oksidativnaya modifikaciya makromolekul: pol'za, vred i zaschita / V.I. Kulinskii // Sorosovskii obrazovatel'nyi zhurnal. - 1999. — № $1 .-$ S.2-7.

4. Miranda, C.L. Cytotoxic and antiproliferative effects of prenylatetchalcones in human cancer cell lines and in cultured ret hepatocytes / C.L. Miranda, J.F. Stevens, A. Helmrich // Food Chem. Toxicol. — 1999. — № 37 (9). — P.271-285.

5. Meksidol: rekomendacii po primeneniyu. - M., 2005. $20 \mathrm{~s}$.

6. Chesnokova, N.P. Obschaya harakteristika istochnikov obrazovaniya svobodnyh radikalov i antioksidantnyh sistem / N.P. Chesnokova, E.V. Ponukalin, M.N. Bizenkova // Uspehi sovremennogo estestvoznaniya (med. nauki). - 2006. № 7 . - S.37-41.

7. Habriev, R.U. Rukovodstvo po eksperimental'nomu (doklinicheskomu) izucheniyu novyh farmakologicheskih veschestv / R.U. Habriev. - M., 2000. - 155 s.

8. Zyuz'kov, G.N. Rol' stvolovyh kletok v adaptacii k gipoksii i mehanizmy neiroprotektivnogo deistviya granulocitarnogo koloniestimuliruyuschego faktora / G.N. Zyuz'kov, N.I. Suslov, A.M. Dygai [i dr.] // Kletochnye tehnologii v biologii medicine. - 2005. - № 4. - S.202-208.

9. Maevskii, E.I. Korrekciya metabolicheskogo acidoza putem podderzhaniya funkcii mitohondrii / E.I. Maevskii. — Puschino: ITEBF RAN, 2001. - $155 \mathrm{~s}$. 